\title{
Article \\ Post-Processing of Cold Sprayed CoNiCrAlY Coatings on Inconel 718 by Rapid Induction Heating
}

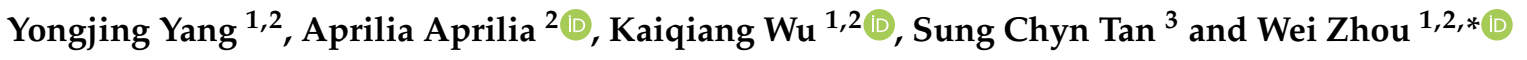 \\ 1 School of Mechanical and Aerospace Engineering, Nanyang Technological University, 50 Nanyang Avenue, \\ Singapore 639798, Singapore; yongjing001@e.ntu.edu.sg (Y.Y.); kaiqiang001@e.ntu.edu.sg (K.W.) \\ 2 Rolls-Royce@NTU Corporate Laboratory, Nanyang Technological University, 65 Nanyang Drive, \\ Singapore 637460, Singapore; aprilia@ntu.edu.sg \\ 3 Rolls-Royce Singapore Pte. Ltd., 1 Seletar Aerospace Crescent, Singapore 797575, Singapore; \\ sungchyn.tan@rolls-royce.com \\ * Correspondence: mwzhou@ntu.edu.sg or wzhou@cantab.net
}

check for updates

Citation: Yang, Y.; Aprilia, A.; Wu, K.; Tan, S.C.; Zhou, W. Post-Processing of Cold Sprayed CoNiCrAlY Coatings on Inconel 718 by Rapid Induction Heating. Metals 2022, 12, 396. https:// doi.org/10.3390/met12030396

Academic Editors: Guijun Bi and Sergey N. Grigoriev

Received: 29 January 2022

Accepted: 22 February 2022

Published: 24 February 2022

Publisher's Note: MDPI stays neutral with regard to jurisdictional claims in published maps and institutional affiliations.

Copyright: (c) 2022 by the authors. Licensee MDPI, Basel, Switzerland. This article is an open access article distributed under the terms and conditions of the Creative Commons Attribution (CC BY) license (https:// creativecommons.org/licenses/by/ $4.0 /)$.

\begin{abstract}
Cold spray is a solid-state additive manufacturing process that has been increasingly used for restoration of damaged parts. Due to the nature of powder solid-state bonding, cold spray coatings usually possess pores in the microstructures. Heat treatment has been widely used as a postprocessing method to reduce the porosity of cold sprayed coatings. However, it usually requires the whole component to be treated in the furnace and typically takes a few hours to finish the treatment. This study aims to develop a localized and rapid post-processing method for cold sprayed coatings. Multi-layer cold sprayed coatings of CoNiCrAlY on an Inconel 718 substrate were produced. Then the coatings were heat treated at $800{ }^{\circ} \mathrm{C}, 900{ }^{\circ} \mathrm{C}, 1000^{\circ} \mathrm{C}$ and $1100{ }^{\circ} \mathrm{C}$ by rapid induction heating. The porosity level of the coatings reduced significantly after induction heating for a short period of merely $10 \mathrm{~min}$. This is attributed to the preferential Joule heating at pore regions, which results in pore closures within the coatings. The potential application of induction heating as a rapid post-processing method for cold spray coatings has been demonstrated in this work.
\end{abstract}

Keywords: cold spray; additive manufacturing; post-processing; induction heating; porosity; preferential heating

\section{Introduction}

Cold spray is an effective solid-state additive manufacturing technique. During the cold spray process, the preheated feedstock particles are accelerated to supersonic speed to hit the substrate, and then the particles would bond on the substrate with a fine microstructure through severe plastic deformation to form the coating [1,2]. Since the temperature is below the melting temperatures of the materials during the cold spray process, cold sprayed coatings usually contain less oxidation and less thermally induced distortion than the thermal sprayed coatings. Due to the advantages of the cold spray technique, it has been increasingly applied to repair damaged aerospace components.

Inconel 718 is a nickel-based superalloy that has been extensively used to make aerospace components such as gas turbine blades due to its excellent mechanical performance [3]. To provide more reliable performance and durability of the nickel-based superalloy at high temperatures, an appropriate coating is usually required to avoid the component damage. MCrAlY (where $\mathrm{M}=\mathrm{Ni}$, Co, or both) alloy has been widely used in thermal barrier coatings (TBCs) as the bond coat layer to provide corrosion and oxidation protection for nickel-based superalloys in harsh environments [4].

There has been considerable research on the preparation of MCrAlY coating by thermal spray [5-13]. Scrivani et al. [6] reported that the quality of MCrAlY coatings prepared by vacuum plasma spray is better than that prepared by high velocity oxygen fuel or axial plasma spray. 
In the recent decade, some research has been carried out to study cold sprayed MCrAlY coatings [14-18]. For instance, Li et al. [14] reported that such coatings present a better thermal fatigue resistance than that of the low-pressure plasma sprayed coatings. Khanna et al. [15] found that the cold sprayed CoNiCrAlY coatings exhibit considerable improvement in wear and oxidation resistance compared with the high velocity oxy fuel coatings.

Although the cold sprayed coatings present desirable properties, the inter-particle bonding is usually limited in the as-sprayed condition, because the atomic diffusion is relatively restricted at low temperatures during the cold spray process [19]. The quality and performance of the coatings are affected by the poor inter-particle bonding and the porosity in the coatings [20]. Therefore, post-process treatment is sometimes carried out to improve the quality of the as-deposited coatings.

Maharjan et al. [21] reported that both deep cold rolling and controlled hammer peening are effective in reducing porosity and enhancing the bonding strength of cold spayed Ti-6Al-4V coatings. This method has the advantage of being a localized processing technique. However, the mechanical peening process may result in a higher surface roughness and the minimum achievable porosity level is relatively high at $2.67 \%$.

Heat treatment is the most widely used method for post-processing of cold sprayed coatings. Boruah and Zhang [22] reported that the interfacial bonding strength of cold sprayed Ti-6Al-4V coating on Ti-6Al-4V substrate increased remarkably after $1 \mathrm{~h}$ of solution treatment at $940{ }^{\circ} \mathrm{C}$ followed by $8 \mathrm{~h}$ of aging at $480{ }^{\circ} \mathrm{C}$, but it should be noted that the whole post heat treatment process is very long. The effect of post heat treatment at $350{ }^{\circ} \mathrm{C}$ for $4 \mathrm{~h}$ on cold sprayed A380 composites was revealed by Qiu et al. [23]. After the long period of heat treatment, the plasticity of the sample enhanced significantly, but the porosity increased slightly. Ren et al. [24] reported that the porosity only decreased slightly after heat treatment at $850{ }^{\circ} \mathrm{C}$ for $4 \mathrm{~h}$ in the cold sprayed Ti samples, while the majority of the large pores remained unaffected, except for a shape change. According to Huang et al. [25], the porosity of cold sprayed Ti coatings decreased by about half after heat treatment at $1000{ }^{\circ} \mathrm{C}$ for $4 \mathrm{~h}$, but the porosity level was still high at 7.6\%. Al-Mangour et al. [26] studied the effect of heat treatment temperatures from $400{ }^{\circ} \mathrm{C}$ to $1100{ }^{\circ} \mathrm{C}$ on cold sprayed $316 \mathrm{~L}$ stainless steel and found that the largest porosity reduction occurred at the highest heat treatment temperature of $1100{ }^{\circ} \mathrm{C}$ for $1 \mathrm{~h}$. Generally, heat treatment at high temperatures is found to improve the quality of cold sprayed coatings; however, it usually requires the whole component to be put in the furnace chamber and usually takes a few hours to finish the whole process due to the low heating rate.

Chen et al. [27] studied the effect of hot isostatic pressing (HIP) on the porosity and mechanical properties of cold sprayed Ti-6Al-4V alloy. After HIP at $920^{\circ} \mathrm{C}$ and $120 \mathrm{MPa}$ for $2 \mathrm{~h}$, the porosity in the sample was reduced to a negligible level of $0.037 \%$. Nevertheless, HIP also takes a long processing time (typically a few hours), and it also requires the whole component to be put into the chamber for heating and pressing, and it is a much more expensive post-processing method than conventional heat treatment.

For aerospace repair, the prolonged heating of the whole component during the conventional post heat treatment or HIP leads to very low productivity and could have an adverse effect on the base metal. Therefore, a localized and rapid heat treatment method would be desirable. Induction heating is a non-contact rapid heating process by locally induced eddy currents. A previous study revealed that the localized repair of Inconel 718 can be achieved by induction heating within a very short period of 2 min [28]. However, there is little information about the effect of induction heating on the cold sprayed coatings.

The objective of the current research was to develop an effective localized and rapid post-processing method for pore closure of cold sprayed coatings via induction heating. In this study, cold sprayed CoNiCrAlY coatings on an Inconel 718 substrate were induction heat treated at different temperatures for the same soaking time, and then the microstructures were characterized. 


\section{Materials and Methods}

\subsection{Materials}

Gas-atomized Diamalloy 4700 CoNiCrAlY powder purchased from Oerlikon Metco (Pfäffikon, Switzerland) was used as feedstock in the cold spray process. The powder morphology and size distribution are shown in Figure 1. Inconel 718 (Haynes International, Kokomo, IN, USA) with $8 \mathrm{~mm}$ thickness was used as the substrate. The substrate was ground and cleaned in ethanol prior to the cold spray process. The chemical composition of the materials is shown in Table 1.
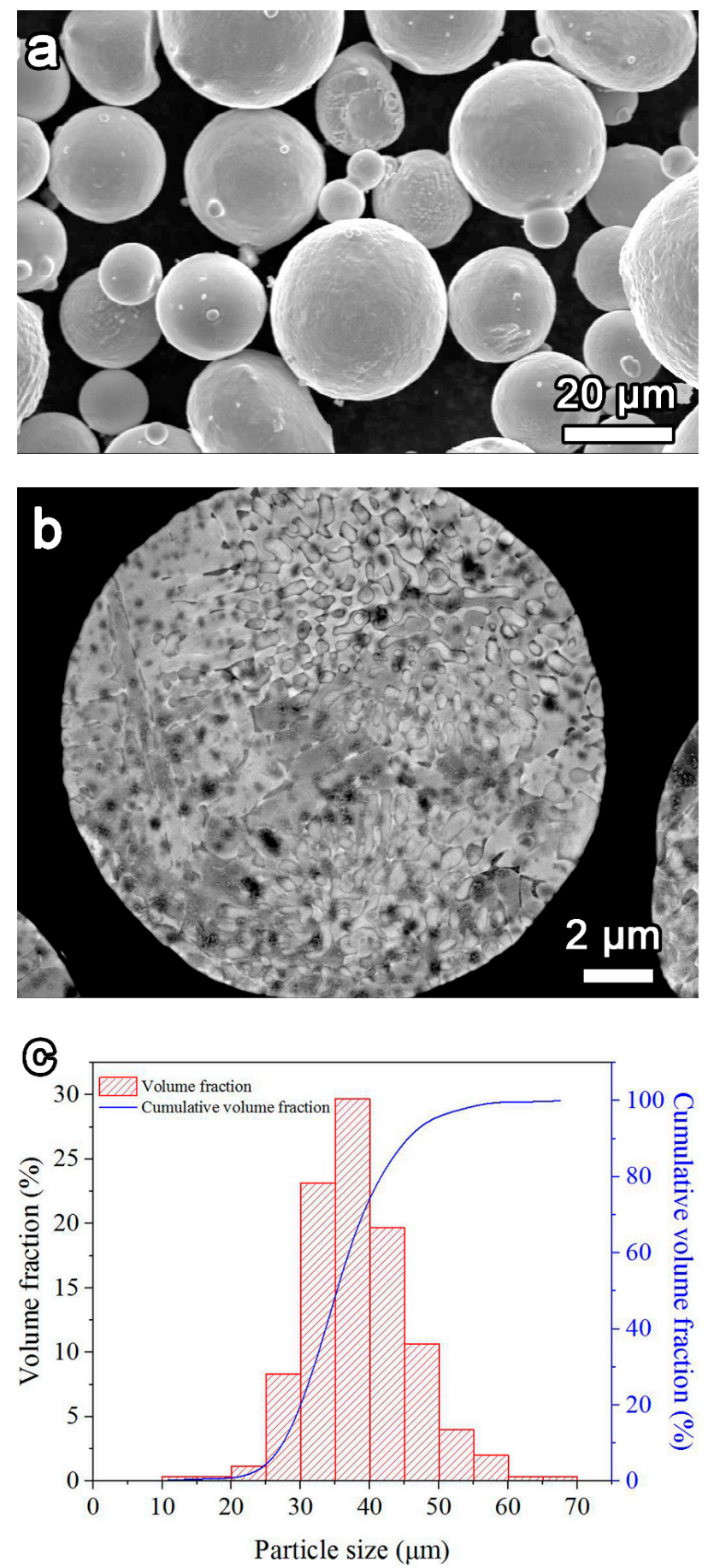

Figure 1. SEM micrographs of CoNiCrAlY powder feedstock showing (a) surface morphology and (b) cross-section microstructure. (c) Size distribution of CoNiCrAlY particles. 
Table 1. Chemical composition of the materials used in this study.

\begin{tabular}{ccccccccccc}
\hline \multirow{2}{*}{ Materials } & \multicolumn{7}{c}{ Chemical Composition (wt\%) } \\
\cline { 2 - 10 } & Co & Ni & Cr & Al & Fe & Y & Mo & Nb & Ti \\
\hline CoNiCrAlY & 38.4 & 31.9 & 21.0 & 8.0 & - & 0.5 & - & - \\
Inconel 718 & 0.31 & 52.9 & 18.3 & 0.52 & 18.5 & - & 3.06 & 5.06 & 0.98 \\
\hline
\end{tabular}

\subsection{Cold Spray}

Cold spray deposition was performed using a high-pressure system (Impact Innovations $\mathrm{GmbH}$, Rattenkirchen, Germany) through a SiC nozzle with an exit diameter of $6 \mathrm{~mm}$. The feed rate of the CoNiCrAlY powder was about $45 \mathrm{~g} / \mathrm{min}$. Pure nitrogen was used as the propellant gas at a temperature of $1000{ }^{\circ} \mathrm{C}$ and a pressure of about $4.5 \mathrm{MPa}$. The temperature and pressure used were close to the capacity of the cold spray system in order to gain a high particle velocity [2,29]. The average particle velocity was $746 \mathrm{~m} / \mathrm{s}$, which was calculated from 600 particles measured by a cold spray meter (CSM EVOLUTION, Tecnar Automation Inc., Saint-Bruno-de-Montarville, QC, Canada).

During the deposition, the traverse speed of the spray gun was $500 \mathrm{~mm} / \mathrm{s}$, the step size of each spray pass was $1 \mathrm{~mm}$, and the stand-off distance was $30 \mathrm{~mm}$. The coating consisted of 10 layers with a total coating thickness of about $850 \mu \mathrm{m}$.

\subsection{Induction Heating}

After the cold spray deposition, the samples were heat treated via induction heating equipment (GH Induction Atmospheres, Rochester, NY, USA). This equipment uses a high-frequency power supply with the frequency set at $107 \mathrm{kHz}$. It is equipped with a bell jar system which allows the samples to be heated in a vacuum environment. The vacuum environment prevents surface oxidation during the heating process. The bell jar's vacuum pressure was set to about $5 \times 10^{-4}$ torr before induction heating was carried out.

For each induction heating process, the samples were positioned with the coating sides facing an induction coil of $30 \mathrm{~mm}$ in diameter. The stand-off distance was fixed at $5 \mathrm{~mm}$. The experimental setup is shown in Figure 2. The samples were heated and held at target temperatures of $800{ }^{\circ} \mathrm{C}, 900{ }^{\circ} \mathrm{C}, 1000^{\circ} \mathrm{C}$ and $1100^{\circ} \mathrm{C}$ respectively for the same period of $10 \mathrm{~min}$. The temperatures selected were all within the heat treatment temperature range commonly used for CoNiCrAlY coatings [11,30,31].

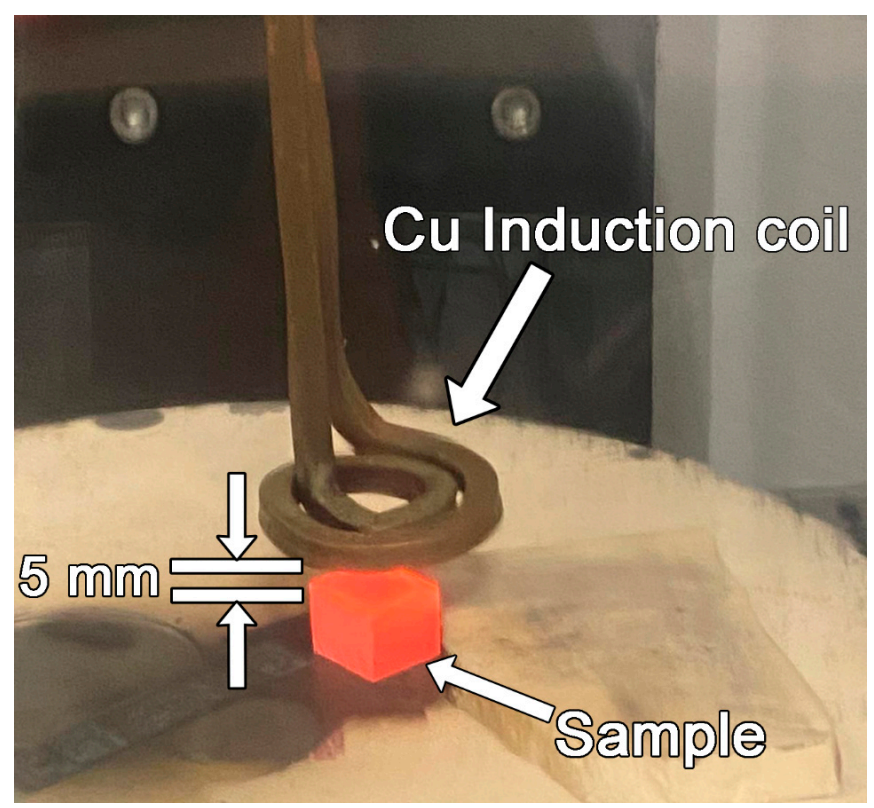

Figure 2. Experimental setup of induction heating of the cold sprayed samples. 
After the time was up, the samples were cooled inside the bell jar in its vacuum environment for $5 \mathrm{~min}$ and then in an argon environment for another $5 \mathrm{~min}$ before they were taken out of the bell jar to the open air.

\subsection{Microstructural Characterization}

Prior to microstructural observation, the samples were mounted, ground, and polished to mirror-like finish. The microstructures were observed using an LEXT OLS4000 laser confocal microscope (Olympus, Tokyo, Japan) and a JEOL-7600 scanning electron microscope (JEOL, Tokyo, Japan). The porosity percentages were measured using ImageJ software (NIH, Bethesda, MD, USA), with ten optical micrographs collected for each sample using the $20 \times$ objective lens of the LEXT OLS4000 microscope. The average values and standard deviations were then calculated from the ten measured data.

Electron backscattered diffraction (EBSD, Oxford Instruments, Abingdon, UK) was conducted using a step size of $0.2 \mu \mathrm{m}$ at an accelerating voltage of $20 \mathrm{kV}$, and then the analysis was performed with Channel 5 (Oxford Instruments, Abingdon, UK) software.

Microhardness measurements were carried out on the cross-sections using a FutureTech FM-300e Vickers microhardness indenter (Future-Tech, Kawasaki, Japan). An indenter load of $200 \mathrm{gf}$ and dwell duration of $10 \mathrm{~s}$ were used. Ten microhardness data were collected for each location of interest to get the average microhardness and standard deviation.

\section{Results and Discussion}

Figure 3 shows the cross-section microstructures of the cold sprayed CoNiCrAlY coatings and the porosity percentage before and after induction heating. As shown in Figure $3 \mathrm{a}$, the pores were uniformly distributed in the as-sprayed coating, and the porosity percentage of the as-sprayed coating was measured to be $3.1 \%$. After induction heating at $800{ }^{\circ} \mathrm{C}$, the porosity percentage was found to be reduced to $2.1 \%$. For induction heating at $900{ }^{\circ} \mathrm{C}$, the porosity percentage was further reduced to $1.6 \%$, which was almost half of the porosity in the as-sprayed coating. Further increasing the temperature to $1000{ }^{\circ} \mathrm{C}$ led to even further reduction of the porosity percentage to $0.7 \%$.

It can be observed that the porosity level of the coatings decreased with the increase in the induction heating temperature. The most significant reduction of the porosity occurred in the induction-heated sample at the highest temperature of $1100{ }^{\circ} \mathrm{C}$, where the porosity was reduced to $0.3 \%$, which is about one tenth of the as-sprayed sample's porosity. Saeidi et al. [30] reported that the porosity reduced in the CoNiCrAlY coating due to a sintering effect after being heat treated at $1100{ }^{\circ} \mathrm{C}$ for $3 \mathrm{~h}$ in a vacuum. It should be noted that the time used in this work was only $10 \mathrm{~min}$, which is significantly shorter than that in the previous work using the same heat treatment temperature.

In our previous study, the porosity percentage of the cold sprayed coatings was below $0.2 \%$ and did not show significant difference after induction heating from $800{ }^{\circ} \mathrm{C}$ to $1100{ }^{\circ} \mathrm{C}$ [32]. This could be attributed to the low magnification of the images used for porosity measurement $(4 \times$ objective lens only). When an image with low magnification was chosen, the small pores could not be resolved or identified clearly. Therefore, the porosity percentage was much lower in the previous study. To improve the accuracy of the porosity measurement, more optical micrographs with a higher magnification $(20 \times$ objective lens) were used in the current study.

Another important engineering issue for coatings is their bonding with the substrate. Some voids were observed at the coating-substrate interface in the as-sprayed coating and after induction heating at $800{ }^{\circ} \mathrm{C}$, as shown in Figure 3a,b. Such features indicate low interfacial bonding strength. As shown in Figure $3 c-e$, after induction heating at or above $900{ }^{\circ} \mathrm{C}$, no obvious unbonded regions were observed at the interface. The elimination of the voids at the interface could be attributed to the improved diffusion of the constituent elements between the coating and the substrate at higher induction heating temperatures. 

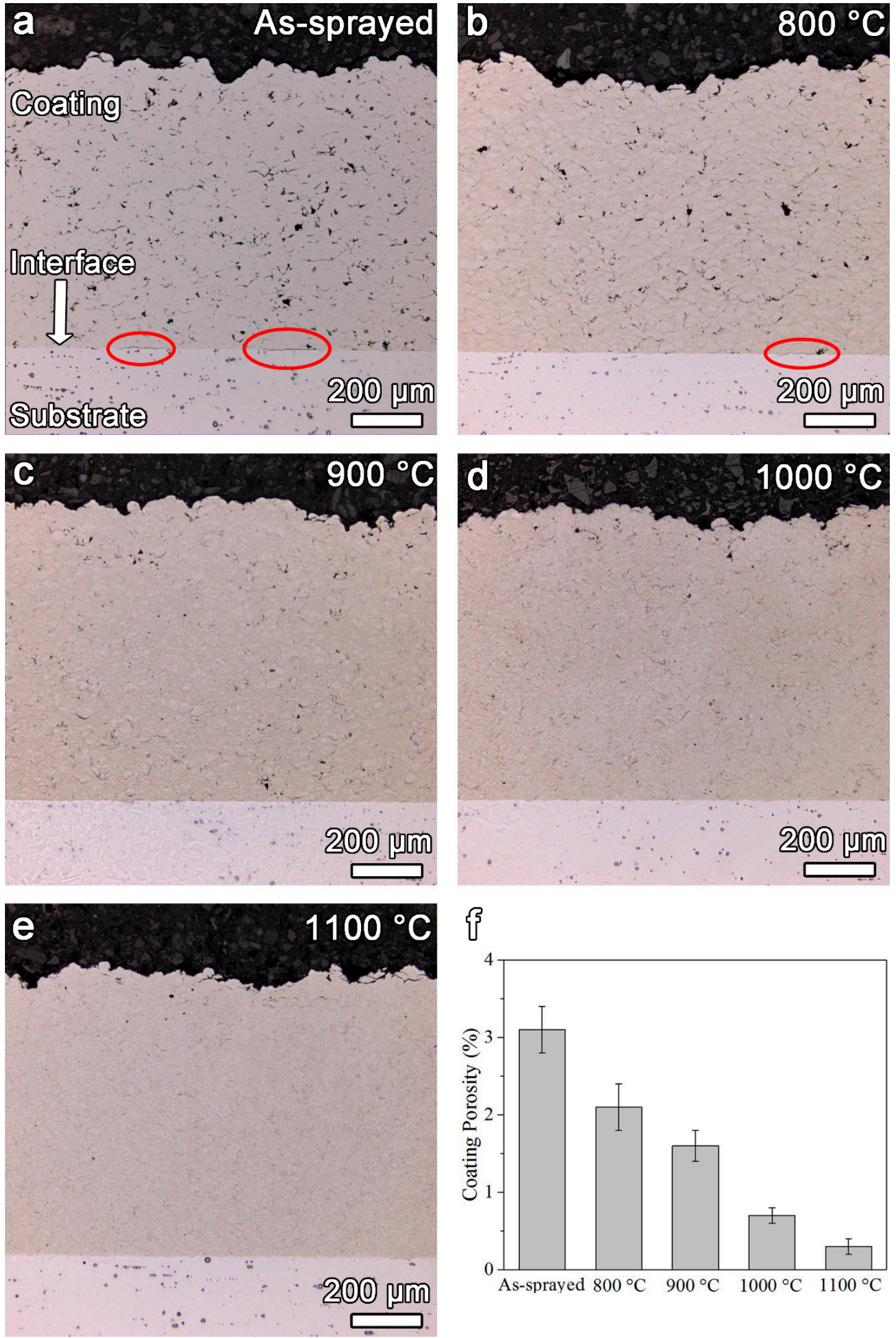

Figure 3. Optical microscope observation of the cross-sections of the cold sprayed samples: (a) assprayed, (b) $800{ }^{\circ} \mathrm{C}$, (c) $900{ }^{\circ} \mathrm{C}$, (d) $1000{ }^{\circ} \mathrm{C}$ and (e) $1100{ }^{\circ} \mathrm{C}$. (f) Porosity percentage of cold sprayed samples depending on the induction heating temperature. The red ellipses indicate areas with interfacial debonding. 
Figure 4 shows the top surface morphologies of the cold sprayed samples before and after induction heating. The relatively big gap was observed in the as-sprayed sample (as indicated by the red ellipses in Figure 4a), indicating poor bonding between the particles. In the as-sprayed sample, the bonding of the particles was formed through plastic deformation. Due to the low atomic diffusion rate in the solid state, the bonding of the particles is usually weak. After induction heating, because of the enhanced diffusion effect by the eddy current and Joule heating, the bonding of the particles improved, as marked by the yellow ellipses in Figure 4b,c.
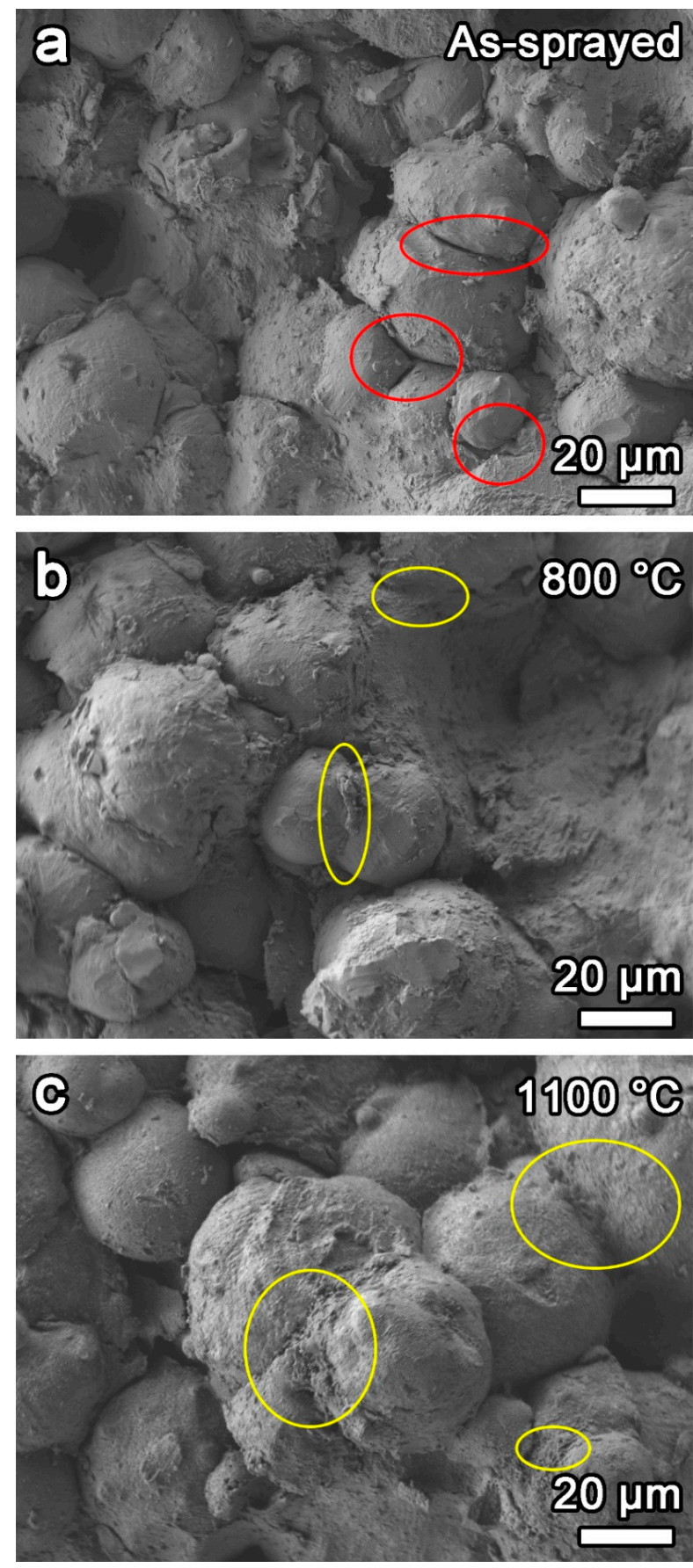

Figure 4. SEM images of the surface morphologies of cold sprayed CoNiCrAlY coatings: (a) assprayed, (b) induction heating at $800{ }^{\circ} \mathrm{C}$ and (c) induction heating at $1100{ }^{\circ} \mathrm{C}$. The red and yellow ellipses indicate areas with poor and good inter-particle bonding, respectively. 
To further reveal the effect of the induction heating temperature on the microstructure of the cold sprayed coatings, backscattered electron SEM images are presented in Figure 5. Figure 5a shows large pores at the particle boundary regions in the as-sprayed coating. These pores were caused by the poor inter-particle bonding, as can be clearly seen in the higher magnification image in Figure $5 b$. As shown in Figure $5 c, d$, after induction heating at $800{ }^{\circ} \mathrm{C}$, some inter-particle pores were still observed, although the pores became smaller compared with those in the as-sprayed sample. After induction heating at $900{ }^{\circ} \mathrm{C}$ and above, the particle boundaries in the coatings became indistinguishable. An almost pore-free microstructure was achieved at an induction heating temperature of $1100{ }^{\circ} \mathrm{C}$, and no gap between the particles was observed, as shown in Figure 5i,j.
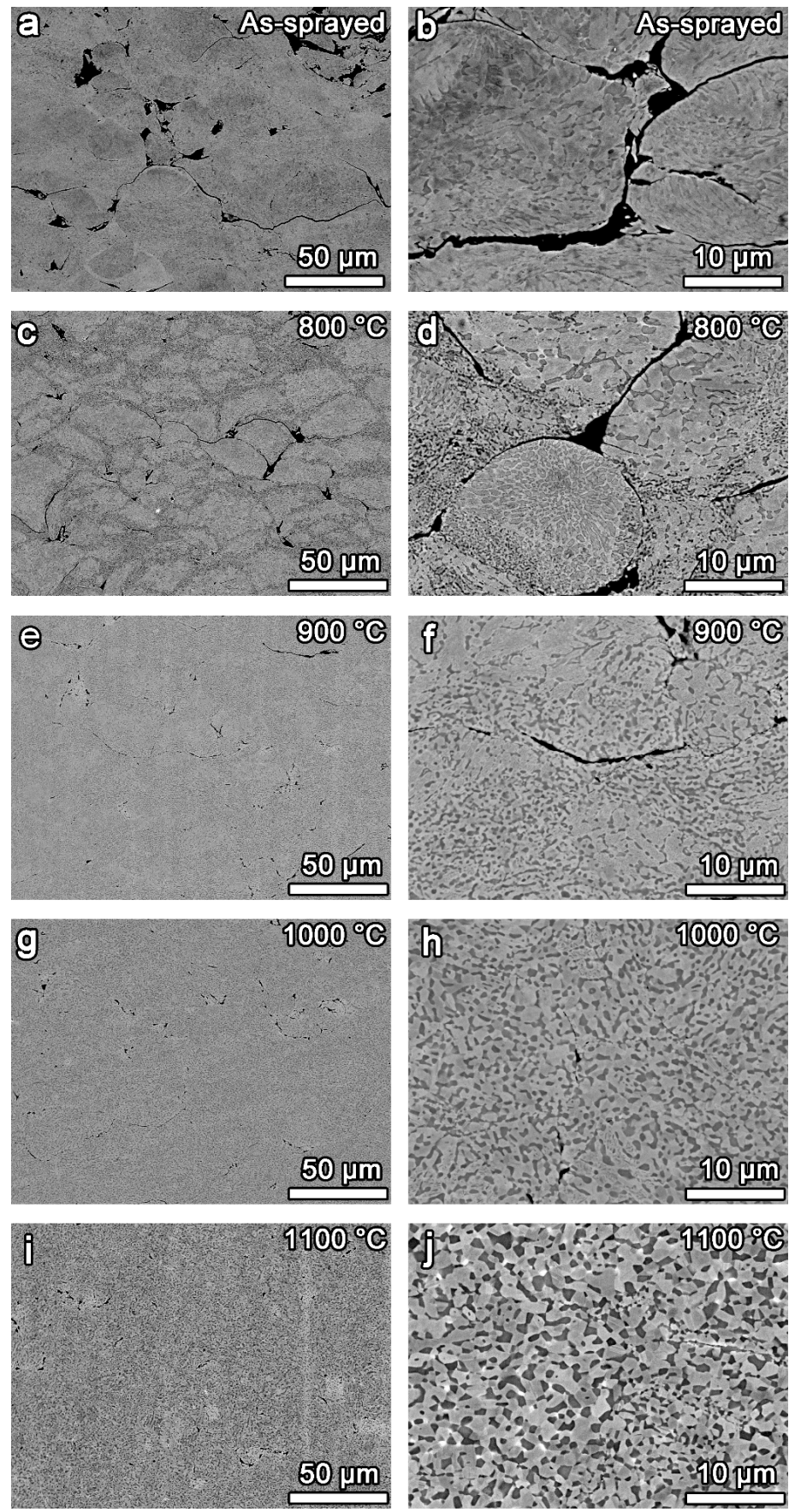

Figure 5. Backscattered electron micrographs showing the microstructures of the cold sprayed coatings: (a,b) as-sprayed, (c,d) $800^{\circ} \mathrm{C},(\mathbf{e}, \mathbf{f}) 900^{\circ} \mathrm{C},(\mathbf{g}, \mathbf{h}) 1000^{\circ} \mathrm{C}$ and $(\mathbf{i}, \mathbf{j}) 1100^{\circ} \mathrm{C}$. 
Figure 6 presents the EBSD results of the cold sprayed coatings after induction heating at different temperatures. As shown in Figure 6a, large unindexed black areas were observed in the inverse pole figure (IPF) map after induction heating at $800{ }^{\circ} \mathrm{C}$. This could be attributed to the following two factors. First, the EBSD scan step size used was $0.2 \mu \mathrm{m}$, so grains smaller than this size could not be indexed. Second, due to the severe plastic deformation in the cold spray process, high strain would occur in the coatings, thus lowering the index rate $[29,33]$ if the strain was not fully relieved at the lowest treatment temperature. With the increase of induction heating temperature, the degree of strain relief increases [34], and the grains grow in size. Therefore, a much higher index rate was achieved, as shown in Figure $6 \mathrm{~b}-\mathrm{d}$. The grain size of the cold sprayed coatings after induction heating is shown in Figure 6e.
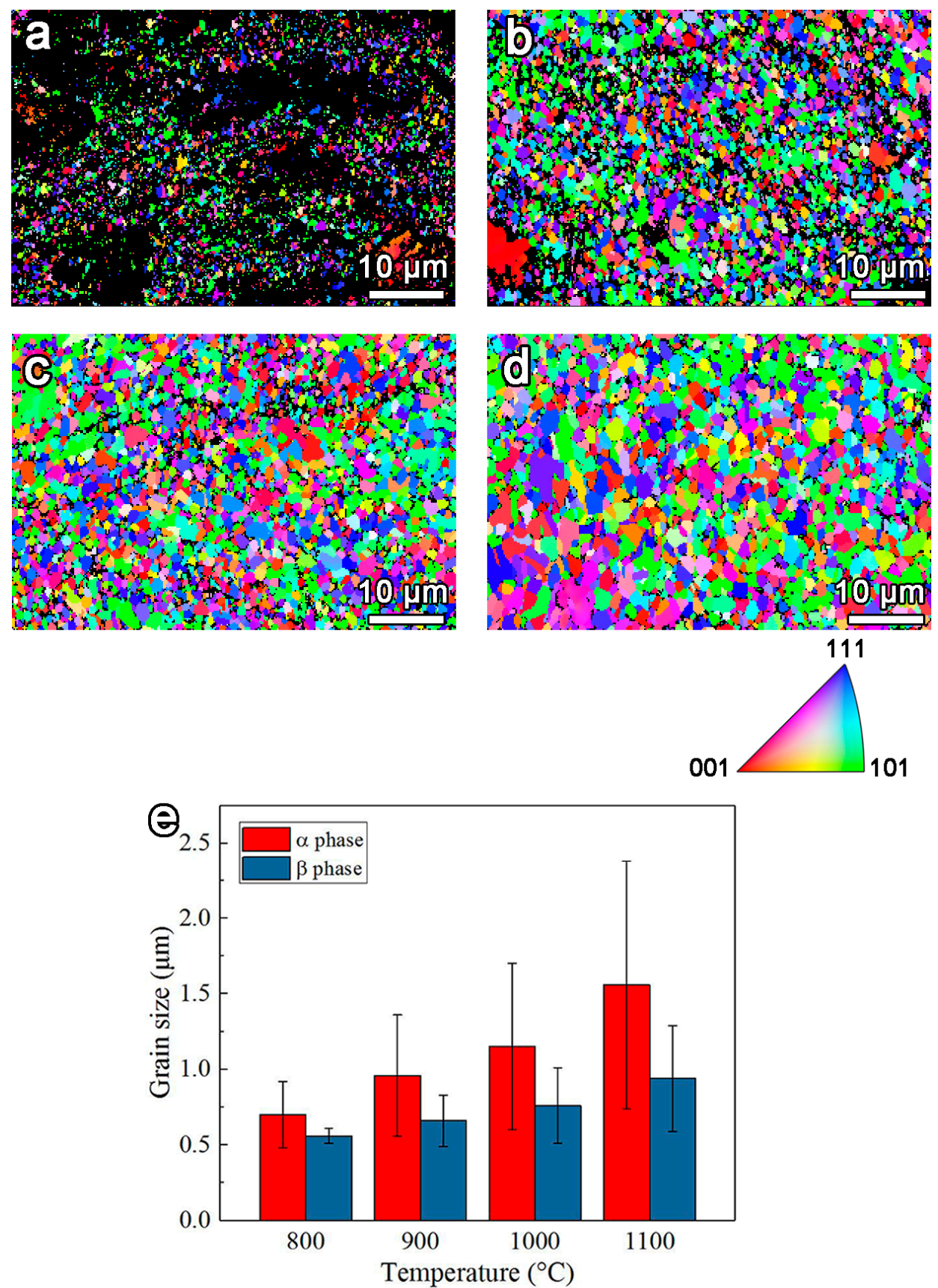

Figure 6. IPF maps of the cold sprayed CoNiCrAlY coatings: (a) $800{ }^{\circ} \mathrm{C}$, (b) $900{ }^{\circ} \mathrm{C}$, (c) $1000{ }^{\circ} \mathrm{C}$ and (d) $1100{ }^{\circ} \mathrm{C}$. (e) Grain size of the deposited coatings after induction heating. 
Induction heating is a non-contact method to heat the sample rapidly by the eddy current. The pores have almost infinite electrical resistivity, so the eddy current cannot go through them in the cold sprayed coatings. This would cause the current to detour and crowd around the pores as shown in Figure 7a. This would lead to the preferential Joule heating around these regions (Figure $7 \mathrm{~b}$ ), resulting in closure of the pores (Figure $7 \mathrm{c}$ ). This mechanism is similar to the mechanism of crack healing by electropulsing [35].

a

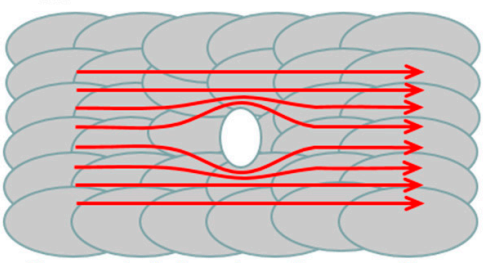

Current detouring \& crowding b

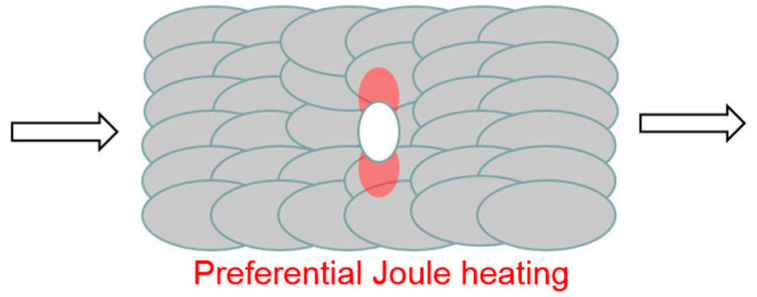

C



Figure 7. Schematic graph of the preferential heating induced pore closure by induction heating.

The microhardness results of the coatings before and after induction heating are shown in Figure 8. The microhardness of the as-sprayed CoNiCrAlY coatings was measured to be $519 \pm 21 \mathrm{HV}$. After induction heating at the lowest temperature of $800{ }^{\circ} \mathrm{C}$, a similar microhardness $(528 \pm 26 \mathrm{HV})$ was obtained. A reduction in the porosity level (Figure $3 \mathrm{f})$ is usually expected to increase the microhardness. However, the strain relief effect tends to reduce the microhardness. As a result, the microhardness value remained similar.

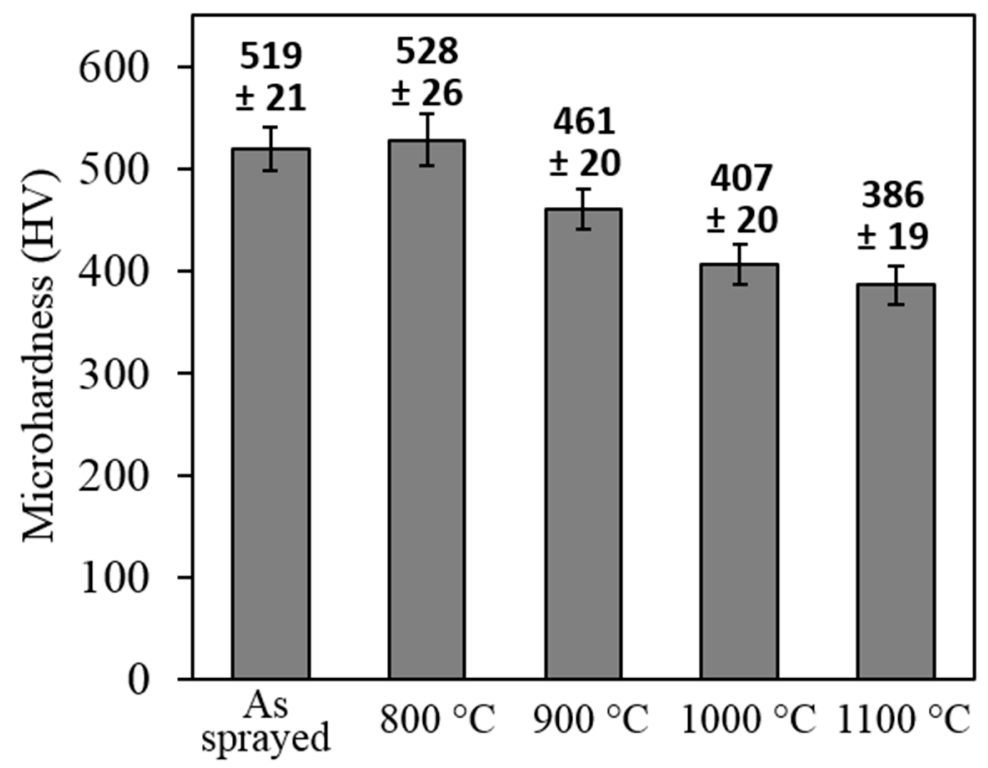

Figure 8. Effect of induction heating temperature on the microhardness of the cold sprayed CoNiCrAlY coatings.

For the coatings which were induction heated at the higher temperatures of $900{ }^{\circ} \mathrm{C}$, $1000{ }^{\circ} \mathrm{C}$ and $1100{ }^{\circ} \mathrm{C}$, decreases in the microhardness were observed (Figure 8). This can be attributed to the grain growth and strain relief with the increase in the processing temperature, as indicated by the EBSD results in Figure 6. It is clear to see from the figure that the grains of the $\alpha$-phase were coarsened (from $0.7 \mu \mathrm{m}$ for $800{ }^{\circ} \mathrm{C}$ to $1.56 \mu \mathrm{m}$ for $1100{ }^{\circ} \mathrm{C}$ ) with the increase of the processing temperature. In the meantime, the grain size of the $\beta$-phase increased from $0.56 \mu \mathrm{m}$ for $800^{\circ} \mathrm{C}$ to $0.94 \mu \mathrm{m}$ for $1100{ }^{\circ} \mathrm{C}$. The increase in grain size seemed to be small, but the increase was in fact significant since it was an increase of $122.9 \%$ for the $\alpha$-phase and $67.9 \%$ for the $\beta$-phase. Such an increment in grain size can 
result in a noticeable reduction in yield strength [36] and thus a reduction in hardness. The decrease in the microhardness of the CoNiCrAlY coatings after high temperature $\left(900{ }^{\circ} \mathrm{C}\right.$ to $1100{ }^{\circ} \mathrm{C}$ ) heat treatment was also reported by Bardi et al. [8] and Picas et al. [31].

Further microhardness measurements at different locations of the coatings were also carried out. The microhardness of the coatings at the locations of $250 \mu \mathrm{m}, 500 \mu \mathrm{m}$ and $750 \mu \mathrm{m}$ from the coating-substrate interface was measured. The results are shown in Figure 9. No significant variation of the microhardness was observed with the different locations in the coatings, indicating the quality of the coating is almost homogeneous.



Figure 9. Variation of the microhardness of the cold sprayed coatings at different locations from the substrate-coating interface.

\section{Conclusions}

In this study, CoNiCrAlY coatings were deposited on an Inconel 718 substrate using a high-pressure cold spray system and then post-processed by induction heating. The microstructures and microhardness were carefully characterized. The main conclusions are as follows:

(1) A localized and rapid post-processing method for cold sprayed coatings was developed through the use of a bell jar for creating a local vacuum and the use of induction for rapid heating.

(2) After the cold sprayed coatings were processed at $800{ }^{\circ} \mathrm{C}, 900{ }^{\circ} \mathrm{C}, 1000{ }^{\circ} \mathrm{C}$ and $1100{ }^{\circ} \mathrm{C}$ for a short period of merely $10 \mathrm{~min}$, the porosity level was found to reduce significantly. With the increase of temperature, the porosity was reduced and the inter-particle bonding was enhanced to achieve the microstructural improvement. At the highest temperature of $1100^{\circ} \mathrm{C}$, the coatings contained only $0.3 \%$ porosity, which was about one tenth of the porosity in the as-sprayed coatings.

(3) During induction heating, preferential Joule heating occurs around the pores due to current crowding and detouring, resulting in closure of the pores.

(4) The microhardness of the CoNiCrAlY coatings reduced after induction heating at $900{ }^{\circ} \mathrm{C}$ and higher temperatures, and this is attributed to the grain growth and strain relief. 


\begin{abstract}
Author Contributions: Conceptualization, W.Z. and Y.Y.; methodology, W.Z.; validation, Y.Y., A.A. and S.C.T.; formal analysis and investigation, Y.Y., A.A. and K.W.; data curation, Y.Y. and A.A.; writing—original draft preparation, Y.Y.; writing—review and editing, W.Z., Y.Y., A.A., K.W. and S.C.T.; visualization, Y.Y. and A.A.; supervision, W.Z.; project administration, W.Z.; funding acquisition, W.Z. and S.C.T. All authors have read and agreed to the published version of the manuscript.
\end{abstract}

Funding: This research was funded by the National Research Foundation of Singapore, Rolls-Royce Singapore Pte. Ltd., and Nanyang Technological University through grants \#002123-00002 and \#002124-00002.

\title{
Institutional Review Board Statement: Not applicable.
}

Informed Consent Statement: Not applicable.

Data Availability Statement: Not applicable.

Acknowledgments: This study was supported under the RIE2020 Industry Alignment FundIndustry Collaboration Projects (IAF-ICP) Funding Initiative, as well as cash and in-kind contributions from Rolls-Royce Singapore Pte. Ltd.

Conflicts of Interest: The authors declare no conflict of interest.

\section{References}

1. Neo, R.G.; Wu, K.; Tan, S.C.; Zhou, W. Effect of spray distance and powder feed rate on particle velocity in cold spray processes. Metals 2022, 12, 75. [CrossRef]

2. Wu, K.; Chee, S.W.; Sun, W.; Tan, A.W.Y.; Tan, S.C.; Liu, E.; Zhou, W. Inconel 713C coating by cold spray for surface enhancement of Inconel 718. Metals 2021, 11, 2048. [CrossRef]

3. Luu, D.N.; Zhou, W.; Nai, S.M.L.; Yang, Y. Mitigation of solute segregation during solutionization of selective laser melted Inconel 718 through micron-TiC addition. J. Alloys Compd. 2021, 897, 163224. [CrossRef]

4. Padture, N.P.; Gell, M.; Jordan, E.H. Thermal barrier coatings for gas-turbine engine applications. Science 2002, 296, 280-284. [CrossRef]

5. Higuera, V.; Belzunce, F.J.; Riba, J. Influence of the thermal-spray procedure on the properties of a CoNiCrAlY coating. Surf. Coat. Technol. 2006, 200, 5550-5556. [CrossRef]

6. Scrivani, A.; Bardi, U.; Carrafiello, L.; Lavacchi, A.; Niccolai, F.; Rizzi, G. A comparative study of high velocity oxygen fuel, vacuum plasma spray, and axial plasma spray for the deposition of CoNiCrAlY bond coat alloy. J. Therm. Spray Technol. 2003, 12, 504-507. [CrossRef]

7. Tang, F.; Ajdelsztajn, L.; Kim, G.E.; Provenzano, V.; Schoenung, J.M. Effects of surface oxidation during HVOF processing on the primary stage oxidation of a CoNiCrAlY coating. Surf. Coat. Technol. 2004, 185, 228-233. [CrossRef]

8. Bardi, U.; Carrafiello, L.; Groppetti, R.; Niccolai, F.; Rizzi, G.; Scrivani, A.; Tedeschi, F. On the surface preparation of nickel superalloys before CoNiCrAlY deposition by thermal spray. Surf. Coat. Technol. 2004, 184, 156-162. [CrossRef]

9. Waki, H.; Kitamura, T.; Kobayashi, A. Effect of thermal treatment on high-temperature mechanical properties enhancement in LPPS, HVOF, and APS CoNiCrAlY coatings. J. Therm. Spray Technol. 2009, 18, 500-509. [CrossRef]

10. Keller, I.; Naumenko, D.; Quadakkers, W.J.; Vaßen, R.; Singheiser, L. Influence of vacuum heat treatment parameters on the surface composition of MCrAlY coatings. Surf. Coat. Technol. 2013, 215, 24-29. [CrossRef]

11. Poza, P.; Grant, P.S. Microstructure evolution of vacuum plasma sprayed CoNiCrAlY coatings after heat treatment and isothermal oxidation. Surf. Coat. Technol. 2006, 201, 2887-2896. [CrossRef]

12. Li, C.J.; Li, W.Y. Effect of sprayed powder particle size on the oxidation behavior of MCrAlY materials during high velocity oxygen-fuel deposition. Surf. Coat. Technol. 2002, 162, 31-41. [CrossRef]

13. Puetz, P.; Huang, X.; Lima, R.S.; Yang, Q.; Zhao, L. Characterization of transient oxide formation on CoNiCrAlY after heat treatment in vacuum and air. Surf. Coat. Technol. 2010, 205, 647-657. [CrossRef]

14. Li, Y.; Li, C.J.; Yang, G.J.; Xing, L.K. Thermal fatigue behavior of thermal barrier coatings with the MCrAlY bond coats by cold spraying and low-pressure plasma spraying. Surf. Coat. Technol. 2010, 205, 2225-2233. [CrossRef]

15. Khanna, A.S.; Rathod, W.S. Development of CoNiCrAlY oxidation resistant hard coatings using high velocity oxy fuel and cold spray techniques. Int. J. Refract. Met. Hard Mater. 2015, 49, 374-382. [CrossRef]

16. Guo, D.; Wang, Y.; Fernandez, R.; Zhao, L.; Jodoin, B. Cold spray for production of in-situ nanocrystalline MCrAlY coatings-Part I: Process analysis and microstructure characterization. Surf. Coat. Technol. 2021, 409, 126854. [CrossRef]

17. Karaoglanli, A.C.; Turk, A. Isothermal oxidation behavior and kinetics of thermal barrier coatings produced by cold gas dynamic spray technique. Surf. Coat. Technol. 2017, 318, 72-81. [CrossRef]

18. Richer, P.; Yandouzi, M.; Beauvais, L.; Jodoin, B. Oxidation behaviour of CoNiCrAlY bond coats produced by plasma, HVOF and cold gas dynamic spraying. Surf. Coat. Technol. 2010, 204, 3962-3974. [CrossRef]

19. Sun, W.; Tan, A.W.Y.; Wu, K.; Yin, S.; Yang, X.; Marinescu, I.; Liu, E. Post-process treatments on supersonic cold sprayed coatings: A review. Coatings 2020, 10, 123. [CrossRef] 
20. Chen, H. Microstructure characterisation of un-melted particles in a plasma sprayed CoNiCrAlY coating. Mater. Charact. 2018, 136, 444-451. [CrossRef]

21. Maharjan, N.; Bhowmik, A.; Kum, C.; Hu, J.; Yang, Y.; Zhou, W. Post-processing of cold sprayed Ti-6Al-4V coatings by mechanical peening. Metals 2021, 11, 1038. [CrossRef]

22. Boruah, D.; Zhang, X. Effect of Post-Deposition Solution treatment and ageing on improving interfacial adhesion strength of cold sprayed Ti6Al4V coatings. Metals 2021, 11, 2038. [CrossRef]

23. Qiu, X.; Tariq, N.U.H.; Qi, L.; Wang, J.Q.; Xiong, T.Y. A hybrid approach to improve microstructure and mechanical properties of cold spray additively manufactured A380 aluminum composites. Mater. Sci. Eng. A 2020, 772, 138828. [CrossRef]

24. Ren, Y.Q.; King, P.C.; Yang, Y.S.; Xiao, T.Q.; Chu, C.; Gulizia, S.; Murphy, A.B. Characterization of heat treatment-induced pore structure changes in cold-sprayed titanium. Mater. Charact. 2017, 132, 69-75. [CrossRef]

25. Huang, R.; Sone, M.; Ma, W.; Fukanuma, H. The effects of heat treatment on the mechanical properties of cold-sprayed coatings Surf. Coat. Technol. 2015, 261, 278-288. [CrossRef]

26. Al-Mangour, B.; Mongrain, R.; Irissou, E.; Yue, S. Improving the strength and corrosion resistance of 316L stainless steel for biomedical applications using cold spray. Surf. Coat. Technol. 2013, 216, 297-307. [CrossRef]

27. Chen, C.; Xie, Y.; Yan, X.; Yin, S.; Fukanuma, H.; Huang, R.; Zhao, R.; Wang, J.; Ren, Z.; Liu, M.; et al. Effect of hot isostatic pressing (HIP) on microstructure and mechanical properties of Ti6Al4V alloy fabricated by cold spray additive manufacturing. Addit. Manuf. 2019, 27, 595-605. [CrossRef]

28. Aprilia, A.; Tan, J.L.; Yang, Y.; Tan, S.C.; Zhou, W. Induction brazing for rapid localized repair of inconel 718. Metals 2021, 11, 1096. [CrossRef]

29. Wu, K.; Sun, W.; Tan, A.W.Y.; Marinescu, I.; Liu, E.; Zhou, W. An investigation into microstructure, tribological and mechanical properties of cold sprayed Inconel 625 coatings. Surf. Coat. Technol. 2021, 424, 127660. [CrossRef]

30. Saeidi, S.; Voisey, K.T.; McCartney, D.G. The effect of heat treatment on the oxidation behavior of HVOF and VPS CoNiCrAlY coatings. J. Therm. Spray Technol. 2009, 18, 209-216. [CrossRef]

31. Picas, J.A.; Punset, M.; Menargues, S.; Martín, E.; Baile, M.T. Microstructural and tribological studies of as-sprayed and heat-treated HVOF $\mathrm{Cr}_{3} \mathrm{C}_{2}-\mathrm{CoNiCrAlY}$ coatings with a CoNiCrAlY bond coat. Surf. Coat. Technol. 2015, 268, 317-324. [CrossRef]

32. Yang, Y.; Wu, K.; Aprilia, A.; Tan, S.C.; Zhou, W. Post-processing of cold spray coatings via rapid induction heating. In International Conference on Advanced Surface Enhancement, Proceedings of the 2nd International Conference on Advanced Surface Enhancement (INCASE 2021), Singapore, 7-8 September 2021, 1st ed.; Springer: Singapore, 2022; pp. 168-172.

33. Guo, J.; Amira, S.; Gougeon, P.; Chen, X.G. Effect of the surface preparation techniques on the EBSD analysis of a friction stir welded AA1100-B4C metal matrix composite. Mater. Charact. 2011, 62, 865-877. [CrossRef]

34. Bhowmik, A.; Tan, A.W.Y.; Sun, W.; Wei, Z.; Marinescu, I.; Liu, E. On the heat-treatment induced evolution of residual stress and remarkable enhancement of adhesion strength of cold sprayed Ti-6Al-4V coatings. Results Mater. 2020, 7, 100119. [CrossRef]

35. Yang, C.; Xu, W.; Guo, B.; Shan, D.; Zhang, J. Healing of fatigue crack in 1045 steel by using eddy current treatment. Materials 2016, 9, 641. [CrossRef]

36. Zhai, W.; Zhou, W.; Nai, S.M.L. In-situ formation of TiC nanoparticles in selective laser melting of 316L with addition of micronsized TiC particles. Mater. Sci. Eng. A 2022, 829, 142179. [CrossRef] 